\title{
Critical Study of Aushadhi Sevana Kala with special reference to Chronopharmacology
}

\author{
Dr. Archana R. Belge ${ }^{1}$, Dr. Omprakash W. Talokar ${ }^{2}$, Dr. Raman S. Belge ${ }^{3}$ \\ ${ }^{1}$ Reader, Dept. of Swasthavritta, Shree Saptashrungi Ayurved College, Nashik, Maharashtra, India. \\ ${ }^{2}$ Associate Professor, Dept. of Rasashastra \& Bhaishajya Kalpana, R.T. Ayurved College, Akola, Maharashtra, \\ India. \\ ${ }^{3}$ Reader, Dept. of Rasashastra \& Bhaishajya Kalpana, Shree Saptashrungi Ayurved College, Nashik, \\ Maharashtra, India.
}

\begin{abstract}
Chronobiology is the Science dealing with the phenomenon of Biological rhythmicity in living organisms. Chronopharmacology is the branch dealing with the Pharmacologic aspects of Chronobiology.The knowledge of rhythmic temporal patterns is essential for effective Ayurvedic treatments. The different Aushadhi Sevana Kalas are defined according to the biological clocks. The ultimate goal of attaining equilibrium in the Doshas and Dhatus can very well be done by suggesting a proper Aushadhi Sevana Kala. The present article is an attempt made to have a Critical Study of Aushadhi Sevana Kala with special reference to Chronopharmacology.

Key Words: Aushadhi Sevana Kala, Chronopharmacology, Circadian Rhythms
\end{abstract}

\section{Introduction:}

The drug optimization can be achieved through Chronopharmacology. Chronopharmacology is the Science that deals with the variations in the pharmacological actions of various drugs over a period of 24 hours of the day. The biochemical, physiological and pathological variations of the 24 hour period in humans had been well described in the Ayurvedic texts although the Modern Science was not much aware of it until the $20^{\text {th }}$ Century.

The Pharmacokinetics and Pharmacodynamics of a medication and nutrients are directly affected by the endogenous biological rhythm. The effectiveness of many drugs varies depending on the dosage administration time associated with 24 hours biological rhythm under the control of circadian clock ${ }^{1}$.

Circadian rhythms are self-sustaining endogenous oscillations occurring in a period of 24 hours. The circadian rhythms are related to the normal sleep-wake cycle. These rhythms are controlled by Suprachiasmatic nuclei $(\mathrm{SCN})$ that are situated in the hypothalamus and the pineal gland. This master clock network regulates the circadian clocks located in cells, tissues and organ-systems.

The chronopharmacologic approaches tend to reduce the side effects and to make the drug more bioavailable. The conventional homeostatic approach is replaced by the proper study of Chronopharmacology. The Chronopharmacological principle is used in the therapy of Myocardial Infarction, diabetes, hypertension, bronchial asthma, arthritis, hypercholesterolemia etc ${ }^{2}$.

Aushadhi Sevana Kala is the type of Avasthika Kala ${ }^{3}$, meant for the proper time of drug-administration. Agni, being the supreme factor for maintaining Dhatu-samyata, all the therapies are directed to maintain and preserve the potency of Agni. The proper knowledge of Agni and food / drug interaction is helpful to attain a quick and sustainable relief to the patient.

Chikitsa kala depends upon the following factors ${ }^{3}$.

1) Dina - e.g. Vamana- Pratahkala, Anuvasana Basti-after light food intake

2) Rugna -e.g. Pratah nirannakala

3) Aushadha -e.g. Samudga, Sagrasa, Grasantare

4) Vyadhi -e.g. Jvara- 6 hourly Peya consumption.

5) Jirnalinga -e.g. Laghuta, Udgar, Pradipta Kshudha

6) Rutu -e.g. Vasanta- Kaphapropaka

The present paper deals with the Aushadha Sevana Kala.

\section{Number of Aushadhi Sevana Kala:}

The ancient texts of Ayurveda have described 10 types of Aushadhi Sevana Kalas. These texts differ about the nomenclature of Kalas as seen from the Tables no. 1, 2, 3\& 4. However, the division done by Charaka is largely accepted by the Vaidyas. 
III. The detailed descriptions of Aushadhi Sevana Kalas are as follows:

3.1Niranna Kala

- Bheshaja is administered on empty stomach.

- Bheshaja is not mixed with food.

- Hemadri- once the consumed food is digested, Bheshaja is given and after its digestion, food is given.

- Indu- Bheshaja is given 2 hours after sunrise.

Activity of Bheshaja:-

- Highly potent due to No Contact of Bheshaja with food.

- Bheshaja Virya- Unchanged.

- Agni \& Bheshaja- Interaction unobstructed due to absence of food.

\section{Indications:-}

- Agni-Avastha- Pradipta Agni

- Disease- prabala Vyadhi

- Patient- In Durbala Rugna- to be taken after laghu \& pathyahara.

\section{Contra-Indications:}

- Debility

- Children, Pregnancy, Female patient

- Doshakshaya, Dhatukshaya

Side-effect:-

- Severe Balakshaya

- Glani

\section{Physiology of the Sharira:-}

- Amashaya and strotasas are rikta of Kapha

- Bheshaja interacts directly with agni

- Agni, viz. Jatharagni, Bhutagni and Dhatvagni could be stimulated.

- Accomplishment of the Saptadhatu Prashastatva. So useful for the Rasayana Sevana

\subsection{Pragbhakta Kala}

- Bheshaja is administered before meals.

- Hemadri-Bheshaja intake is immediately followed by food.

Activity of Bheshaja:-

- Ashupaka of Bheshaja.

- No balakshaya, as the food follows the Bheshaja.

- No mechanical expulsion of Bheshaja, due to intake of food.(Urdhwagati Pratibandha).

\section{Indications:-}

- Dosha- Apanavayu Vikruti

- Disease- Debility, weakness of lower parts of Body, mutravaha-malavaha-shukravaha strotasas, pakvashayagata vyadhi, Arsha, Gudabhransha.

\section{Physiology of the Sharira:-}

- The Bheshaja intake is followed by food. Thus it is the first target of Agni \& not the food.

- The Bheshaja directly acts on the Amashaya \& eradicates the vitiated doshas.

\subsection{Madhyabhakta Kala}

- Bheshaja is administered in between meals.

- Chakrapani \& Indu- 50\% food intake $\rightarrow$ Bheshaja $\rightarrow$ remaining food intake.

\section{Activity of Bheshaja:-}

- Bheshaja- acts locally \& eradicates the Sthanic doshas.

- Stimulaton of the Samana vayu. 


\section{Indications:-}

- Dosha- Samanavayu Vikruti, pitta

- Agni- Mandagni

- Disease- Koshthagatavyadhi, pakvashayagata vyadhi, shula, gulma, grahani

\section{Physiology of the Sharira:-}

- The Urdhwagati and Adhahgati of Bheshaja is restricted by food, so it cannot spread and is forced to act locally.

- The systemic action of the bheshaja on dosha \& dhatu is of sustained release type.

- As Samana Vayu \& Pachaka Pitta are both situated in the Koshtha, this Kala helps to control Paittika \& koshthagata vyadhis, Samanavayudushti.

\subsection{Adhobhakta Kala}

- Bheshaja is administered after meals (after lunch \& dinner).

- Hemadri \& Indu- Bheshaja is to be administered immediately after meals.

- Vyanavikruti- Bheshaja is administered after lunch.

- Udanavikruti- Bheshaja is administered after dinner.

Activity of Bheshaja:-

- The Udanavayu fascilitates the urdhvagati of Bheshaja, thereby strengthening the upper parts of body esp. the sense organs.

\section{Indications:-}

- Dosha- Vyanavayu Vikruti, Udanavayu Vikruti

- Disease-

Vyanavayujanya- napunsakata, debility, shopha, jvara, depression, body ache, tingling, numbness, kushtha, visarpa.

Udanavayujanya- throat-infections, depression, chhardi, aruchi, pinasa, galaganda, urdhvajatrugata vyadhi.

- Karshya

\section{Physiology of the Sharira:-}

- After lunch- stimulation of Vyana vayu.

- After dinner- stimulation of Udana vayu.

\subsection{Antarabhakta Kala}

- Previously consumed food is digested, Bheshaja consumed; after metabolism of Bheshaja, again food is taken in the evening.

Activity of Bheshaja:-

- It shows Hrudya, Pathya, Deepana \& Manobalakara effect.

\section{Indications:-}

- Dosha- Vyanavayu

- Disease-

Vyanavayujanya- napunsakata, debility, shopha, jvara, depression, body ache, tingling, numbness, kushtha, visarpa.

\section{Physiology of the Sharira:-}

- Due to madhyanha i.e. Pittakala, Agni is in a stimulated condition. So Bheshaja is properly metabolized in this kala.

\subsection{Sabhakta Kala}

- Bheshaja is given mixed with food.

- Indu- Bheshaja is processed or cooked along with food or it is given with food.

\section{Activity of Bheshaja:-}

- To potentiate the Agni-Bala. 


\section{Indications:-}

- Disease- Arochaka, aruchi, sarvangasamshrita vyadhis

- Patients- women, old, children, debilitated patients \& those who exhibit unpalatability to medicines. Physiology of the Sharira:-

- Systemic action on the Doshas \& Dhatus is observed.

- The drug mixes with Rasadhatu \& then spreads all over the body through Uddhva-Adhara and Tiryak Gati. Hence useful in Sarvangasamshrita vyadhis.

\subsection{Samudga Kala}

- Bheshaja is administered immediately before \& after food.

- Indu, Hemadri-- Bheshaja should be consumed immediately in relation to food.

- Bheshaja acts as a Samudga (Box) for Ahara.

\section{Activity of Bheshaja:-}

- It helps in correcting the gati vikruti of Vata dosha by promoting anulomana of Vata dosha.

- It promotes Urdhva \& Adhara Gati of the drug.

\section{Indications:-}

- Dosha- Vyana-Apana-Udanavayu

- Type of Dravya- Pachana, Avaleha, Churna

- Disease- Hikka, Kampa, Akshepaka, Vataja Prameha, Shukradosha.

- Patients-a patient who consumes light food.

\section{Physiology of the Sharira:-}

- Hikka- Kapha \& Vata doshas are involved(Ch. Chi. 17/8). Kapha is situated in the Urdhvasharira while Vata in the Adhahsharira. Bheshaja administered in the Samudga Kala pacified Doshas at upper \& lower parts of body.

- Akshepaka- Doshas are localized in Pani \& Pada. (Ch. Chi. 28/150). Samudga Bheshaja acts on both the extremities of the body.

\subsection{Muhurmuhu Kala}

- Bheshaja is frequently administered irrespective of Bhukta or Abhuktavastha.

- Can be given empty stomach.

\section{Activity of Bheshaja:-}

- Sublingual absorption provides faster relief.

- High concentration of drug provides more bio-availability.

- Treats the vitiated doshas in their Sanchaya \& Vegavastha.

\section{Indications:-}

- Disease-

Pranavahastrotogata Vyadhi-- Shvasa, Kasa, Hikka

Udakavahastrotogata Vyadhi - Trushna.

Annavahastrotogata Vyadhi -- Chhardi, Visha

\section{Physiology of the Sharira:-}

- All the indications being life-threatening need immediate therapeutic intervention.

\subsection{Grasa Kala}

- Bheshaja is administered with each \& every morsel of food.

- Arunadatta, Hemadri-Bheshaja is to be mixed with each morsel of food.

\section{Activity of Bheshaja:-}

- Sagrasa Bheshaja facilitates absorption of the bheshaja right from the buccal mucosa.

- High concentration of drug in systemic circulation offers rapid onset of action.

\section{Indications:-}

- Dosha- Pranavayu 
- Agni- To stimulate Agni

- Disease- Pranavayuvikruti (Pinasa, Ardita, trusha, Shvasa)

- Bheshaja- Vajikarana Bheshaja (Churna, Leha, Deepana Dravya, Vati, Guti)

\section{Physiology of the Sharira:-}

- Normal Pranavayu regulates the intake of food.( A.H.Su.12/4). Grasa Kala Bheshaja stimulates the Pranavayu. So the Indriyaprasadana \& Chittaprasadana takes place. This enhances the Vrishya Prabhava of the Vrishya Dravyas.

\subsection{Grasantara Kala}

- Bheshaja is administered between two morsels of food.

\section{Activity of Bheshaja:-}

- It helps in correcting the gati vikruti of Vata dosha by promoting anulomana of Vata dosha.

Indications:-

- Dosha-Pranavayuvikruti

- Type of Dravya- Leha

- Disease- Pinasa, Ardita, Trusha, Shwasa, Hrudroga (A.S.Su.23)

- For Vamana

- For Kasaghna dhuma (Su. Chi. 40/18)

\section{Physiology of the Sharira:-}

- Normal Pranavayu regulates the intake of food.( A.H.Su.12/4). Grasa Kala Bheshaja stimulates the Pranavayu. So the Indriyaprasadana \& Chittaprasadana takes place. This enhances the Vrishya Prabhava of the Vrishya Dravyas.

\subsection{Nisha Kala}

- Bheshaja is administered after digestion of consumed food.

- Indu (A.S.Su.23/18)- Nisha Kala is the time after evening meal is digested and 3 hours have passed.

- Sharangadhara- Anannavastha.

\section{Activity of Bheshaja:-}

- Selective action of the Bheshaja towards the urdhvajatrugata parts because the Adhara gati of drug is prevented by food.

\section{Indications:-}

- Dosha-Kapha

- Type of Dravya- Pachana, Shamana

- Disease- Urdhvajatrugata Vyadhi

- Purpose- Lekhaana, Bruhana (Sa. S.P.1)

\section{Physiology of the Sharira:-}

- Sharangadhara- Ananna Condition

- Ch. Chi. 15/241 - Hrudaya- Mlana, Strotas - Avaruddha, Ahara- Kledakaraka $\rightarrow$ Kapha ++ Pitta + vruddhi, Agni- Manda

- Chiraparinamana of the Shamana Aushadhi takes place.

\section{Limitations of Bhaishajya Kala-}

Meant for Shamana Purpose only. (A.H.Su.13) (Sha. P.K. 2/2)

Instruction for Particular vyadhi where Bhaishajyakala is not specifically mentioned-

- Mentioned specifically for a few Vyadhis like Visha, Kasa, Pipasa (Muhurmuhu) \& Kampa, Akshepaka (Samudga Kala).

- If Bheshaja Kala is not clearly mentioned, it can be decided on the following basis-

1. Dosha - Vatadosha is considered due to its Chalaguna, whereas Pitta \& Kapha doshas are not given prime importance.

2. Dosha sanchaya- e.g. Kaphadosha- abhakta Kala, Vyana/Udana- Adhobhakta Kala

3. Vyadhi Sthana-e.g. Grahani- Madhyebhakta Kala 
4. Vyadhi- Atyayika avastha-e.g. Hikka, Shvasa- Muhurmuhu Kala

5. Agni-Bala-e.g. Pradipta Agni- Niranna Kala

6. Gati of Bheshaja- Urdhva-Adhara-Tiryaka Gatis depend upon the drug / food intake.

\section{Conclusion}

- According to Ayurvedic texts, Chronopharmacology i.e. Aushadhi Sevana Kalas are ten.

- $66 \%$ of Bhaishajya Kala are described in relation to food.

- Sushruta did not mention the Aushadhi Sevans kala as per the Vata - Dushti.

- Meant for Shamana Chikitsa only.

- Oral route of administration is advocated.

- The rate of metabolism of Bheshajya by Agni is controlled by food with the aid of proper Bhaishajya Kala.

- Useful for creating awareness among Biologist, Clinicians \& Pharmacy Scientists.

- Useful to develop new tools for the treatment of classical diseases as well as the modern life - style disorders.

- Already well established active pharmaceutical ingredients can be effectively used for the treatment of various diseases.

- To release the drug at desired time considering the Circadian Rhythm (dosha - Prabhava, Dosha gati)

- The knowledge of Chronopharmacology is useful to improve therapeutic efficacy \& patient compliance.

- Useful to treat the disease caused due to circadian changes in body.

- Useful to maximize desired and minimize undesired side effects.

- For Programmed delivery of medicines.

- Useful to deliver higher amount of drug at a required time.

Table 1

Aushadhi Sevana Kala ${ }^{3}$

\begin{tabular}{|l|l|l|l|}
\hline $\begin{array}{l}\text { Sr. } \\
\text { No. }\end{array}$ & Aushadhikala & Indications & Remarks \\
\hline 1 & Bhuktadau & Apanavikruti & -- \\
\hline 2 & Bhuktamadhye & Samanavikruti & -- \\
\hline 3 & $\begin{array}{l}\text { Bhuktapaschat } \\
\text { a) After lunch } \\
\text { b) After dinner }\end{array}$ & Vyanavikruti Udanavikruti & --- \\
\hline 4 & Muhurmuhu & Shwasa,Kasa, Trishna & \\
\hline 5 & Samudga & Hikka & -- \\
\hline 6 & Bhaktasanyukta & Aruchi & -- \\
\hline 7 & Sagrasa & Pranavayuvikruti & -- \\
\hline 8 & Grasantare & Pranavayuvikruti & -- \\
\hline 9 & Pratah & Balawana Rugna & Empty Stomach \\
\hline 10 & Niranna & Durbala Rugna & To be taken after \\
& & & Laghu Pathyahara \\
\hline
\end{tabular}

Table 2

Aushadhi Sevana Kala ${ }^{4}$

\begin{tabular}{|l|l|l|l|}
\hline $\begin{array}{l}\text { Sr. } \\
\text { No. }\end{array}$ & Aushadhikala & Indications & Remarks \\
\hline 1 & Abhakta & & $\begin{array}{l}\text { C/I Sukumara, Bala, } \\
\text { Vriddha, Streerugna }\end{array}$ \\
\hline 2 & Pragbhakta & & $\begin{array}{l}\text { Shighrapaki, safely be } \\
\text { given in Sukumara, Bala, } \\
\text { Vriddha,Streerugna }\end{array}$ \\
\hline 3 & Adhobhakta & $\begin{array}{l}\text { Urdhvashariragata } \\
\text { Vyadhi, Balya }\end{array}$ & --- \\
\hline 4 & Madhyebhakta & Koshthagata Vyadhi & -- \\
\hline 5 & Antarabhakta & & -- \\
\hline 6 & Sabhakta & Hridya, Manobalavardhaka,Deepana & Streerugna, Nirbala Rugna \\
\hline 7 & Samudga & Urdhwagami \& Adhahgami Dosha & \\
\hline 8 & Muhurmuha & Shwasa, Kasa, Hikka, Vamana & \\
\hline 9 & Grasa & Vajikarana & Leha \\
\hline 10 & Grasantara & Mandagni & \\
\hline
\end{tabular}


Table 3

Aushadhi Sevana Kala ${ }^{5}$

\begin{tabular}{|c|c|c|c|}
\hline Sr. No. & Aushadhikala & Indications & Remarks \\
\hline 1 & Abhakta & Healthy Person & $\begin{array}{l}\text { Unobstructed Strotasas of } \\
\text { Amashaya }\end{array}$ \\
\hline 2 & Pragbhakta & $\begin{array}{l}\text { Diseases of lower half of Body, } \\
\text { Apanavikruti, Obesity }\end{array}$ & \\
\hline 3 & Madhyebhakta & $\begin{array}{l}\text { Samanavikruti, Koshthagata Roga, Pittaja } \\
\text { Roga }\end{array}$ & \\
\hline 4 & Adhobhakta & Urdhvajatrugata Roga & $\begin{array}{l}\text { Vyana- After Lunch } \\
\text { Udana- After Dinner }\end{array}$ \\
\hline 5 & Samabhakta & Sarvangavyadhi & $\begin{array}{l}\text { Useful in balaka, Sukumara \& } \\
\text { those who hate medicines }\end{array}$ \\
\hline 6 & Antarabhakta & Vyanavyadhi & $\begin{array}{l}3 \mathrm{hr} \text {. after lunch/dinner, useful } \\
\text { in those with a better } \\
\text { jatharagni }\end{array}$ \\
\hline 7 & Samudga & $\begin{array}{l}\text { Hikka, Kampa, Akshepa, Urdhva/Adhah } \\
\text { Parshwa Vyadhis }\end{array}$ & $\begin{array}{l}\text { Can be given in the form of } \\
\text { Pachana, Avaleha, Churna }\end{array}$ \\
\hline 8 & Muhurmuha & $\begin{array}{l}\text { Shwasa, kasa, Hikka, Trusha, Chhardi, } \\
\text { Vishaktata }\end{array}$ & Can be given empty stomach \\
\hline 9 & Sagrasa & Pranavayuvyadhi, Vajikarana & $\begin{array}{l}\text { Can be given in the form of } \\
\text { Churna, Leha, Guti, Vati }\end{array}$ \\
\hline 10 & Grasantara & $\begin{array}{l}\text { Pranavayuvyadhi, } \\
\text { Hrudroga }\end{array}$ & \\
\hline 11 & Ratri & $\begin{array}{l}\text { Urdhvajatrugata Vyadhi, Vamana, } \\
\text { Dhumapana }\end{array}$ & \\
\hline
\end{tabular}

Table 4

Aushadhi Sevana Kala ${ }^{6}$

\begin{tabular}{|l|l|l|l|}
\hline $\begin{array}{l}\text { Sr. } \\
\text { No. }\end{array}$ & Aushadhikala & Indications & Remarks \\
\hline 1 & Suryodaya jatah & $\begin{array}{l}\text { Pittaja Vyadhi, Kaphaja Vyadhi, } \\
\text { Virechana, Vamana, Lekhana }\end{array}$ & \\
\hline 2 & $\begin{array}{l}\text { Divasa Bhojane } \\
\text { a)Bhojana Purva } \\
\text { b)Sagrasa } \\
\text { c)Bhojana Madhya } \\
\text { d)Bhojana Pashchat }\end{array}$ & $\mathbf{\square} \quad \begin{array}{l}\text { Apanavikruti } \\
\text { Aruchi } \\
\text { Samanavikruti } \\
\text { Vyanavikruti }\end{array}$ & \\
\hline 3 & $\begin{array}{l}\text { Sayambhojane } \\
\text { a)Grasantaare/ Grase } \\
\text { b)Bhojanapashchat }\end{array}$ & $\begin{array}{l}\text {--Udanavikruti } \\
\text {--Pranavayuvikruti }\end{array}$ & \\
\hline 4 & Muhurmuhu & $\begin{array}{l}\text { Trusha, Chhardi, Hikka, Shvasa, } \\
\text { Garavisha }\end{array}$ & $\begin{array}{l}\text { Medicine can be given } \\
\text { with or without food }\end{array}$ \\
\hline 5 & Nishi & $\begin{array}{l}\text { Urdhvajatrugata Vyadhi, Lekhana, } \\
\text { Bruhana }\end{array}$ & Before dinner \\
\hline
\end{tabular}

Table 5

Various diseases \& their Chronological Behavior ${ }^{7}$

\begin{tabular}{|l|l|l|l|}
\hline $\begin{array}{l}\text { Sr. } \\
\text { No. }\end{array}$ & Disease & Chronological Behaviour & Remarks \\
\hline 1 & Bronchial Asthma & $\begin{array}{l}\text { Precipitation of attack after midnight or at } \\
\text { early morning hours }\end{array}$ & \\
\hline 2 & $\begin{array}{l}\text { Myocardial } \\
\text { Infarction }\end{array}$ & $34 \%$ events occur between 6 AM \& noon & \\
\hline 3 & $\begin{array}{l}\text { Ac. Cardiac arrest \& } \\
\text { Transient Myocardial }\end{array}$ & Increased frequency in Morning & $\begin{array}{l}\text { Cause- Release of } \\
\text { Catecholamines, }\end{array}$ \\
\hline
\end{tabular}


Critical Study of Aushadhi Sevana Kala with special reference to Chronopharmacology

\begin{tabular}{|c|c|c|c|}
\hline & Ischaemia & & $\begin{array}{l}\text { cortisol, Increase in } \\
\text { platelet } \\
\text { aggregation \& } \\
\text { vascular tone. }\end{array}$ \\
\hline 4 & Hypertension & $\begin{array}{l}\text { 6AM-10AM-Systolic BP rise @ 3mm Hg/hr } \\
\text { Diastolic BP rise @ 2mm Hg/hr }\end{array}$ & \\
\hline 5 & $\begin{array}{l}\text { Cerebrovascular } \\
\text { accidents }\end{array}$ & $\begin{array}{l}10 \text { AM- } 12 \text { Noon; Incidence increases during } \\
\text { evening \& midnight }\end{array}$ & \\
\hline 6 & Osteoarthritis & $\begin{array}{l}\text { Worsens in the middle or latter portion of the } \\
\text { day }\end{array}$ & \\
\hline 7 & Rheumatoid arthritis & Pain in early morning compared to day time & $\begin{array}{l}\text { Increased conc. Of } \\
\text { C-reactive proteins } \\
\& \text { interleukin } 6 \text { in } \\
\text { blood }\end{array}$ \\
\hline 8 & $\begin{array}{l}\text { Ankylosing } \\
\text { Spondylitis }\end{array}$ & $\begin{array}{l}\text { Pain intensity } 3 \text { times higher \& stiffness } 8 \\
\text { times higher between 6-9 AM than between } \\
\text { 12-3 PM }\end{array}$ & \\
\hline 9 & Allergic Rhinitis & Worsens in early AM, upon rising & \\
\hline 10 & Peptic ulcer disease & Symptoms worse in the early AM & \\
\hline 11 & $\begin{array}{l}\text { Gastro Intestinal } \\
\text { System }\end{array}$ & Worsens in the early AM & $\begin{array}{l}\text { Most of the drugs } \\
\text { are lipophilic \& } \\
\text { they have more } \\
\text { rate of absorption } \\
\text { in early mornings } \\
\text { rather than any } \\
\text { hour of the day }\end{array}$ \\
\hline 12 & Diabetic mellitus & Increase in Blood Sugar level after meals & \\
\hline 13 & $\begin{array}{l}\text { Attention deficit } \\
\text { syndrome }\end{array}$ & Increase in DOPA level in afternoon & \\
\hline 14 & Cancer & $\begin{array}{l}\text { DNA synthesis in Normal Human Bone } \\
\text { Marrow Cell have a peak around noon } \\
\text { DNA synthesis in Lymphoma Cells is near } \\
\text { Midnight }\end{array}$ & \\
\hline 15 & Depression & $\begin{array}{l}\text { SAD (Seasonal Affective Disorder) in } \\
\text { susceptible people during the short days of } \\
\text { winter }\end{array}$ & \\
\hline$*$ & Growth Hormone & $\begin{array}{l}\text { Secretion is markedly increased during } 12 \\
\text { midnight, but is reduced during the later } \\
\text { stages of sleep }\end{array}$ & \\
\hline
\end{tabular}

Table 6

Suggested Bhaishajya Kala for a few diseases-

\begin{tabular}{|c|c|c|}
\hline Disease & Granthokta Kala & $\begin{array}{l}\text { Suggested Bhaishajya Kala (w.s.r. } \\
\text { to Chronopharmacology) }\end{array}$ \\
\hline 1.Shvasa & Muhurmuhu & $\begin{array}{l}\text { Loading dose at midnight followed by } \\
\text { Maintenance dose at muhurmuhu Kala }\end{array}$ \\
\hline 2. Hypertension & ? Vyanavikruti-- Pratah Bhuktapaschata & Suryodaya jatah (Pratah Kala) \\
\hline $\begin{array}{l}\text { 3. Rheumatoid } \\
\text { Arthritis }\end{array}$ & $\begin{array}{l}\text { ? Sarvangavyadhi } \\
\text { - Samabhakta Kala }\end{array}$ & $\begin{array}{l}\text { Loading dose in the morning (5-6 } \\
\text { am.) followed by maintenance does } \\
\text { at Samabhakta Kala }\end{array}$ \\
\hline $\begin{array}{l}\text { 4. Attention } \\
\text { Deficit } \\
\text { syndrome }\end{array}$ & $\begin{array}{l}\text { ? Manobalavardhaka } \\
\text { - Sabhakta Kala }\end{array}$ & Pratah sabhakta Kala \\
\hline $\begin{array}{l}\text { 5. Growth Hormone } \\
\text { related diseases }\end{array}$ & --- & Nishakala (10 pm. - 12 midnight) \\
\hline 6. Cancer & --- & Nishakala (Near midnight) \\
\hline
\end{tabular}




\section{References}

[1] Davidson's Principles \& Practice of medicine, Christopher Haslett, Edwin R. Chilvers, John A.A. Hunter, Nicholas A. Boon, 20 edition, Churchill Livingstone, 2009, pp. 670

[2] Dr. Manjunatha. T. Sasanoor et al, Importance of Bhaishajya Kala in the Management of Diseases, International Journal of Ayurvedic and Herbal Medicine, 2:2 (2012),pp. 353-365

[3] Caraka, Caraka Samhita In Chikitsasthana 30/296; Shastri Kashinatha, Chaturvedi Gorakhnatha; Chowkhamba Bharati Academy, Varanasi, $20^{\text {th }}$ ed; 1994 Vol. II, pp. 880

[4] Sushruta, Sushruta Samhita In Uttartantra 64/65, Sharma Anantaram, Chowkhamba Surbharati Prakashan, Varanasi, $1^{\text {st }}$ ed., 2004 Vol. II, pp. 570

[5] Vagbhata, Ashtanga Sangraha In Sutrasthana 23/12, Tripathi Ravidatta, Chowkhamba Sanskrit Pratishthan, Dilli, $1^{\text {st }}$ ed. 2001 pp. 428

[6] Sharangdhara, Sharangdhara Samhita In Purvakhanda 2/1-12, Tripathi Brahmananda, Chowkhamba Surbharati Prakashan, Varanasi, $2^{\text {nd }}$ ed., 2006. pp. 24

[7] Smolensky M.H., Reinberg A. Aspects of Human Chronopathology, In Biological Rhythms and Medicine, Cellular, Metabolic, Physiopathologic Aspects, eds. Springer Verlag: New York, pp. 131-209 